International Journal of Linguistics, Literature and Translation

ISSN: 2617-0299 (Online); ISSN: 2708-0099 (Print)

DOI: $10.32996 / \mathrm{ijllt}$

Journal Homepage: www.al-kindipublisher.com/index.php/ijltt

IJLLT

\title{
A Morphological Analysis Focusing on Word Formation Processes of Indonesian Pageant Lover's Register in Instagram Comment
}

\author{
Nurhidayati ${ }^{1} \square$ and DR. Ichwan Suyudi ${ }^{2}$ \\ ${ }^{12}$ Magister Program of Literature, Concentrating on Translation, Gunadarma University, Jakarta, Indonesia \\ $\square$ Corresponding Author: Nurhidayati, E-mail: hidayatilauhul@gmail.com
}

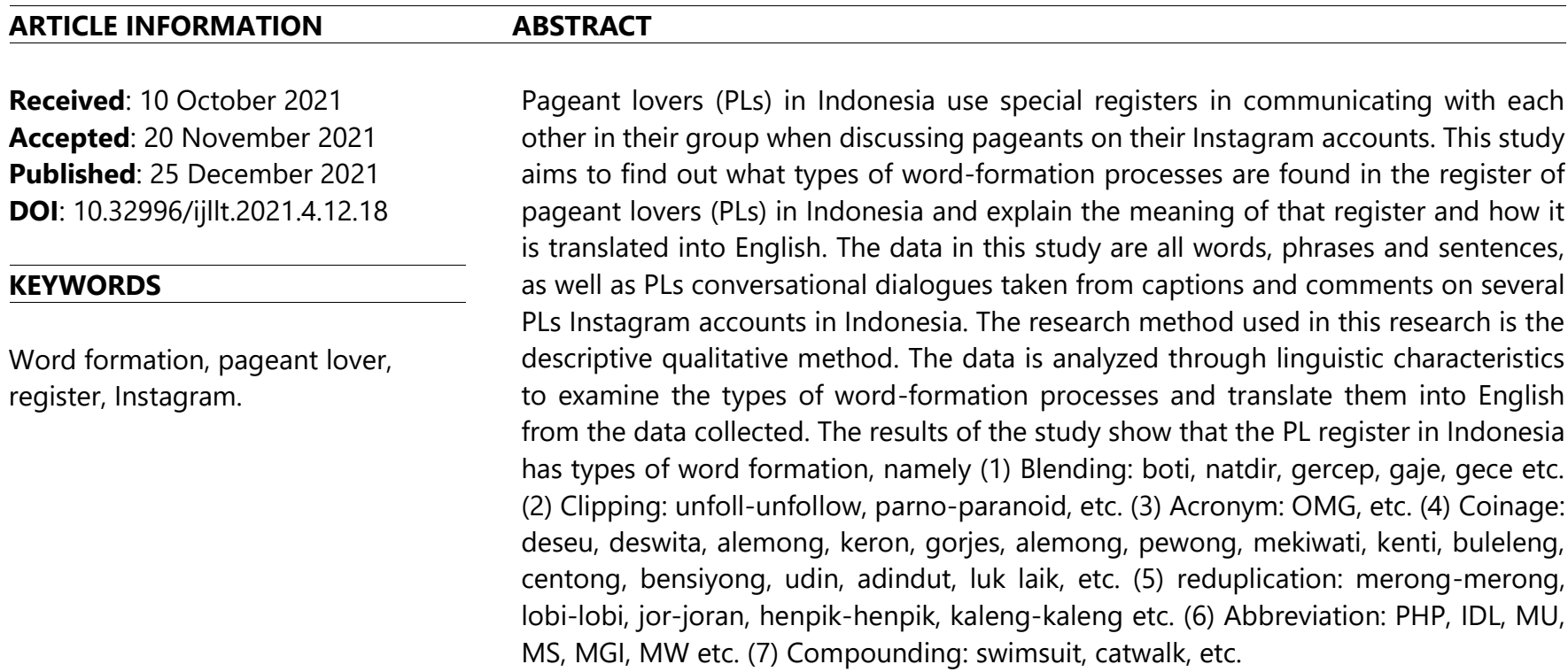

\section{Introduction}

Language is a medium used by people as social creatures who always interact with others to express their thoughts, feelings, and desires so that the message can be received well by others as expected. Using the language is more effective in communicating than others, even though there are actually other ways that can be used to communicate with each other such as gestures, pictures or certain symbols, and other codes.

Language is not only a sign system, especially in sociolinguistic study. It is also used as a social system, a communication system, and a part of the culture of a certain society. There are various social factors that may influence the use of language in social life. Those several social factors are grouped according to gender, social-economic status, occupation, age, education, and so forth. Variation of language used in society can occur due to one of these social factors.

The register is known as one of the language variations that are related to the field of work or social group and situational speech varieties. Wardhaugh (2006) argues that "registers are sets of language items associated with discrete occupational or social groups, particular purposes, in a particular social setting (p.52)". A social group that uses a register may also indicate an inclination on what group they belong to.

Wardhaugh (2006) stated the following:

A social group is a set of two or more people who interact regularly, and in a manner, this is defined by some common purpose, a set of norms and a structure of statuses and roles within the group. It may be measured by reference to such factors as social class, education, and environment. (p.11)

Copyright: (c) 2021 the Author(s). This article is an open access article distributed under the terms and conditions of the Creative Commons Attribution (CC-BY) 4.0 license (https://creativecommons.org/licenses/by/4.0/). Published by Al-Kindi Centre for Research and Development, London, United Kingdom. 
According to the Cambridge dictionary, a pageant or beauty pageant is a competition or show for young women in which they are judged on their beauty, and other qualities are one stage that consists of people wearing traditional clothing and acting out historical events. That definition is also in line with the definition of the pageant in the Oxford dictionary, which stated, "Pageant is public entertainment consisting of a procession of people in elaborate, colourful costumes, or an outdoor performance of a historical scene". The winner of that show is called by a queen who will get the crown, and the follower who is admirer to that show is called pageant lover (PL). They formed a community based on these common purposes and interests to discuss beauty pageants in their community. Pageant lover community starting from discussing beauty contests, the community eventually developed by forming a fan base for the contestants. These sympathizers are like a successful team that works to provide support, facilities to criticism. It can be said, the success of a contestant in the world beauty event cannot be separated from the big role of the successful team behind her.

Pageant lover has their own social group and communicate with each other in their group community by using special codes in their language that is called register. They use the social media platform Instagram to communicate with other pageant lovers. They use their register only when they communicate with each other in their group with the same topics that are about beauty pageants and talk differently to people in a different group. According to one of the Putri Indonesia 2017 success teams Bunga Jelitha, according to her, Pageant Lovers Indonesia was formed from small conversations between beauty pageants lovers Indonesia in cyberspace. From that forum, they created a forum as a means to convey their aspirations to the contestants. The community itself started from a forum called Missology and discussed the issue of the International Pageant. From there emerged the first Indonesian beauty pageant portal called Indo Pageant. Starting from there, it eventually grew, and several fan pages appeared on Instagram," she said when contacted by the KapanLagi.com ${ }^{\circledR}$ team, Sunday $(25 / 02 / 2018)$.

Register of Indonesian pageant lovers (PLs) tends to use informal words and expressions that are not considered standard in the Indonesian language but are considered acceptable in certain social settings that are in their community. The codes and special registers used by these PLs sometimes are only understood by the members of their community and have many differences from the language used to communicate with a different community. The desire to make the group exclusive causes them to create "secret" language, which only applies to their groups. Even though everyone already knows about the language they use, their language is still regarded as secret. The use of language makes these PLs look different from other social groups. The formation of words and meanings of registers are very diverse and depend on the user's creativity.

\section{Literature Review}

According to Coulmas (2005), the functions of PL's registers are divided into several major functions: (1) they are available respect speaker's purposes, (2) they show the manifestation for the member of groups, (3) they build the different identity, (4) they show desirability, and (5) they reject the social norm pressures (p.58). Register that is used by Indonesian PLs has its peculiarities and uniqueness. The use of different terms in communication is generally used to show that the PLs group is different from the other social groups. Consider the utterance "Gaje banget, masa sementer jihane dimentokin (It was not fair, as beautiful as Her doesn't win)". gaje is blending of gak jelas. The example of register used by PLs to express someone who is she male is "Boti banget sih miss pawee (Miss pawe look like she male)". boti is an acronym of bonceng tiga (she male).

\section{Word formation Processes}

Pageant lovers tend to use register when they interact in spoken rather than writing. When they communicate in spoken, pageant lovers usually develop the old word to new word and create new words that have not existed before. The new words that are developed include the using of several special codes and idioms that are created based on word formation processes;

\section{a. Blending}

According to Booij (2007) stated that "blending is the combination of the first of a word with the second part of another word. Blending is a word formed by joining parts of two or older words" (p.309). Blending is the process whereby new words are formed by combining parts of two words, usually the beginning of one word and the end of another, for example, smog (smoke + fog), brunch (breakfast + lunch), heliport (helicopter + airport), motel (motor + hotel), fortran (formula translation).

\section{b. Clipping}

Booij (2007) stated that "clipping is a process in which words are made by removing a part of that word and using the remnant as a word with the same meaning, as in mike from microphone, and ad from advertisement" (p.310). Clipping is also known as "truncation" or "shortening." Clippings are not coined as words belonging to the standard vocabulary of a language. They originate as terms of a special group like schools, army, police, the medical profession, etc., in the intimacy of a milieu where a hint is sufficient to indicate the whole. For example, exam(ination), math(ematics), and lab(oratory) originated in school slang ; spec(ulation) and tick(et = credit) in stock-exchange slang; and vet(eran) and cap(tain) in army slang. While clipping terms of 
some influential groups can pass into common usage, becoming part of Standard English, clippings of a socially unimportant class or group will remain group slang.

c. Coinage (or invention)

Coinage is the process whereby new words are created outright, either deliberately or accidentally, to fit some purpose. Word coinage also refers to the new word that has no basing on any other pre-existing word. Usually, words are coined to express new ideas, processes, products, etc., in the language. For example, brand names such as Xerox, Kodak, Exxon, Kleenex, 8 Nylon, Dacron, etc.; pooch, snob, nerd, blurb, googol, etc.

\section{d. Acronym}

According to Booij (2007) stated that "acronym is a combination of initial letters of a word sequence that is pronounced as a word, not as a combination of letters" (p.307). The acronym is creating a new word formed from the initial letters of the words in a phrase, like an English laser from light amplified by stimulated emission of radiation.

e. Abbreviation

An abbreviation is creating a new word formed from the initial letters of the words. It is pronounced as a combination of letters, as for example, KVA (kilovoltampere).

\section{f. Reduplication}

According to Booij (2007), "reduplication is the morphological operation in which a new word (form) is created by copying a word or a part thereof and affixing that copy to the base. Reduplication consists of the repetition of all or part of a root or stem to form new words" (p.321). If the entire root or stem is repeated, the process is called complete (or total) reduplication, and the new word is considered as a repetitive compound. Total reduplication is frequent in Indonesian, in Indonesian, total reduplication is used to form the plural of nouns, as in [rumah] 'house', [rumahrumah] 'houses'; [ibu] 'mother' [ibuibu] 'mothers'; [lalat] 'fly', [lalatlalat] 'flies'. In Hawaiian, holo means 'run', holoholo 'go for a walk or ride'; lau means 'leaf', laulau 'leaf food package'. If only a part of the root or stem is repeated, the process is called partial reduplication, and the repeated portion is called a reduplicative. Such reduplicative may occur prepose, interposed, and postposed to the root or stem; however, reduplicative are more common word-initially and word-medially. Partial reduplication is common in Snohomish and Tagalog. In English, partial reduplication is a little bit more common than total reduplication. The words are formed by either type of reduplication as reduplicative (also called 'jingles'). As an example of total reduplication, they give bye-bye, goodygoody ('a self-consciously virtuous person'). As to partial reduplication, they say that the constituents of the reduplicative may differ in the initial consonants, as in walkie-talkie, or in the medial vowels, e.g., criss-cross. The same authors add that most reduplicative are highly informal or familiar, and many belong to the sphere of child-parent talk, e.g., din-din (dinner'). In addition, the most common uses of reduplicative are as follow: To imitate sounds, e.g., rat-a-tat (knocking on door), tick-tack (of a clock), ha-ha (of laughter), bow-wow (of dog), to suggest alternating movements, e.g., see-saw, flip-flop, ping-pong, to disparage by suggesting instability, nonsense, insincerity, vacillation, etc., e.g., higgledy-piggledy, hocus-pocus, wishy-washy, dilly-dally, shilly-shally, willy-nilly, to intensify, e.g., teeny-weeny, tip-top.

\section{g. Back formation}

According to Booij (2007) stated that "back-formation is word-formation process in which a less complex word is derived from the more complex word, via removing seeming affixes from existing words, such as forming edit from editor" (p.309). Backformation is the process by which new words are formed by the deletion of a supposed affix from an already existing word; for example, the verbs peddle, edit, hawk, enthuse, stoke, swindle, televise, donate, sculpt, buttle have been created form the pre-existing nouns peddler, editor, hawker, enthusiasm, stoker, swindler, television, donation, sculptor and butler, respectively. The nouns have been thought to be derivatives of verbs on the analogy of cases such as revision, creation, formation, transmission, to name a few, which are true derivatives from the verbs revise, create, form, transmit, respectively. Notice that this process normally involves the transformation of one part of speech into another.

\section{h. Compounding}

According to Booij (2007), compounding is the word-formation process in which compounds are formed by stringing together older words, like the formation of the earthquake from earth and quake" (p.310). A sub-category of compounding is incorporation, which is a compound of a verb and an object or particle, like intake, a compound of the verb take with the preposition in. Compounds can be rather long when translating technical documents from English to some other language, for example, Swedish. "Motion estimation search range settings" can be directly translated torörelseuppskattningssökintervallsinställningar; the length of the word is theoretically unlimited, especially in chemical terminology. 
There are several reasons why the writer chooses this topic. First, the Indonesian PLs register gives many contributions to enrich the Indonesian language with many special terms. Second, the register that is used by PLs in Indonesia is unique and different from the standard Indonesian language. Third, this study indirectly enriches vocabulary and provides its own colour in the Indonesian language development. Even though the register that is used by PLs in Indonesia is very popular, but the use of teenager register will not influence the use of standard Indonesia language because that register is only used when PLs communicate in their own community and many people in the society in the different community do not understand those registers. For several reasons above, this research is intended to give a better understanding of the register used by PLs in Indonesia in their communication.

The purpose of doing this research is (i) to find out the types of word-formation processes of PL's register lexicon in Indonesia. (ii) to find out the meaning of registers frequently used by PLs in Indonesia.

\section{Methodology}

This research is a kind of descriptive qualitative research because it describes and explains the types of word-formation processes and grammatical cohesion of pageant lover registers in Indonesia by exploring the concept or phenomenon. Key (1997) stated that "descriptive research is used to get information concerning the status of phenomena to describe what happens in a condition or situation".

The data of this research were words, phrases, sentences and also a dialogue (text) of pageant lovers (PLs) in caption and comments on Instagram account. There were several instruments for collecting the data. Open the pageant account on Instagram, then read the caption and also the comment that contains PLs register. After that, made the list of the comment and caption that contains PLs registered in a table were also be needed to arrange the data. The table makes the data easier to be analyzed; last, the data were analyzed based on the theory that was formulated. The data were collected by writing down the comment, and the caption of pageant lovers (PLs) registers in pageantry Instagram account. Then, the data are transcribed into Indonesian and English. After all of the PLs registered were marked, the data were tabulated into the table, and after that, the data were analyzed.

\section{Results and Discussion}

Pageant lovers tend to use register when they interact in spoken rather than in writing. When they communicate in spoken, pageant lovers usually develop the old word to new word and create new words that have not existed before. The new words that are developed include the using of several special codes and idioms that are created based on word formation processes;

1. Word formation processes of pageant lovers' register in Indonesia

a. Blending e.g: Boti banget sih miss pawee!

meaning: miss Pawee acted just like she male

boti is a blending process, its process whereby new words are formed by combining parts of two words, usually the beginning of one word and the end of another, boti (bonceng+tiga)

b. Clipping

e.g: Unfoll lapaknya, anyepin

meaning: unfollow the account and then ignore it

analysis:

the word unfoll, which is from the word unfollow, is a clipping process, where the process in which words are made by removing a part of that word and using the remnant as a word with the same meaning.

c. Coinage (or invention)

e.g: Liatlah bapak-bapak buleleng memberi tepukan mandjah

meaning: Please look at those foreign men who give her the sweet applause 
The word buleleng is a coinage process which is the process whereby new words are created outright, either deliberately or accidentally, to fit some purpose. Word coinage also refers to the new word that has no basing on any other preexisting word.

d. Acronym

e.g., OMG, can't waiitt

meaning: Oh My God, can't wait

OMG is an acronym from Oh My God, which is a combination of initial letters of a word sequence that is pronounced as a word, not as a combination of letters

e. Abbreviation e.g: Kirim deseu ke $\mathbf{M U}$ aja kuy, hendpik2

meaning: send her to Miss Universe please, by handpick

The word $M U$ is an abbreviation process that creates a new word from the initial letters of the words. It is pronounced as a combination of letters.

f. Reduplication

e.g: Ntar merong-merong dah tuh akun pengabdi keron

meaning: Crown devotee will get angry about that

The word merong-merong is a reduplication process which is the morphological operation in which a new word (form) is created by copying a word or a part thereof and affixing that copy to the base. Its reduplication consists of the repetition of all or of part of a root or stem to form new words.

g. Compounding compounding is the

e.g., MW gak ada swimsuit Bambang, MU mah sampai kiamat pun gak bakal ngeapus swimsuit

Meaning: There's no swimsuit session at MW bro, MU won't even delete the swimsuit until the end of the world swimsuit is a compounding process in which compounds are formed by stringing together older words, like the formation of a swimsuit from swim and suit.

Table 1. Word formation processes of Pageant lovers Register in Indonesia

\begin{tabular}{|l|c|c|}
\hline \multicolumn{1}{|c|}{ Types of word formation processes } & frequency & percentage \\
& & \\
\hline Blending & 5 & $9.43 \%$ \\
\hline clipping & 3 & $5.67 \%$ \\
\hline Coinage & 27 & $50.94 \%$ \\
\hline Back formation & - & $0 \%$ \\
\hline compounding & 3 & $5.67 \%$ \\
\hline Reduplication Total & 9 & $16.98 \%$ \\
\hline acronym & 1 & $1.88 \%$ \\
\hline abbreviation & 5 & $9.43 \%$ \\
\hline & 53 & $100 \%$ \\
\hline
\end{tabular}

From table 1 above, there were only 7 types of word-formation processes from 8 of whole types of word formation that were found in the source of data. The types of word formation processes commonly used by a teenager in communication among them can be seen. From the table above, it can be seen that teenagers mostly use the types of the blending process in Padang rather than other types. 53 words belong to blending, and then it is followed by the coinage process ( 27 words), abbreviation ( 5 words), 
reduplication (9 words), acronym (1 word), clipping (3 words), and compounding (3). From all of the word formation's types that have been mentioned above, there is no type of word formation that can be categorized as a back formation process that is found based on the finding of this research.

\section{Conclusion}

Pageant lovers in Indonesia tend to communicate on social media platforms (Instagram) using special codes that are only understood by their community. They create and make a new word or reconstruct the old word to be a new word. In creating new words, they used several word formation processes, such as blending $(9.43 \%)$, e.g. boti from bonceng tiga, coinage $(50.94 \%)$, e.g. deseu, deswita, alemong), clipping (5.67\%), e.g. unfoll- unfollow, parno-paranoid, cius miapah ? - serius demi apa ?), acronym (1.88\%), e.g., awak rancak tapi indak salasai, abbreviation (9.43\%), e.g. PHP- pemberi harapan palsu, Reduplication (16.98\%), e.g. merong-merong,lobi-lobi, jor-Joran, henpik-henpik, and compounding (5.67\%).

The writer found some interesting characteristics of morphological analysis of pageant lover registers in Indonesia different from other fields/group communities of register. After collecting all of the data, the researcher found 53 special words of PL's register in Indonesia, which belong to word formation processes. The coinage process is dominant than other types of word formation processes. There is no back formation process found in PL's register in Indonesia. There are several reasons why PLs in Indonesia tend to use those special words in communication among them. They wanted to make their group exclusive and different from the others group. They want to secret something, so the other groups do not know what they say. Therefore, pageant lovers in Indonesia create special vocabularies, which belong to word-formation processes in the process of making those words.

Related to the previous study by Damayanti's (2005) about "Register komunitas musik di beberapa restoran dan hotel berbintang di Surakarta (Register of Music Community on Several Restaurant and Starred Hotel in Surakarta)." From the data analysis, the conclusion of lexicogrammatical features of the music community was reached: (1) Community Music uses various terms or specific vocabulary to communicate. (2) The term or specialized vocabulary is used as a variety of conversations that occur in the music community, as well as having its own meaning. (3) Conversations that contain specialized vocabulary in the music community have functions to the stated intention of the conversation.

In short, every group community has a special register in communication among them. In other words, different group communities have different ways, codes, and register to communicate with each other between the members of the group. They use their own register based on their own reason. The researcher suggests that other researchers who want to do the same research about wordformation processes can choose other group registers, subject and theory as the main focus.

Funding: "This research received no external funding."

Conflicts of Interest: "The authors declare no conflict of interest."

\section{References}

[1] Booij, G. (2007) The Grammar of Word: An Introduction to Morphology. Oxford University Press.

[2] Collins, P and Carmella H (2000). English Grammar an Introduction. Palgrave.

[3] Coulmas, F (2005). Sociolinguistics: The study of speaker's choice. Cambridge University Press.

[4] Gerot, L. and Peter W. (1994). Making sense of Functional Grammar. Gerd Stabler

[5] Gilbert, S. F. (2003). Prenatal Development. Human Development. McGraw Hill College.

[6] Halliday, M. A. K. and Hasan R. (1976). Cohesion in English. Longman.

[7] Holmes, J. (2001). An Introduction to Sociolinguistics. Longman 2nd edition.

[8] O'Grady, W, Michael D. and Francis K (1997). Contemporary Linguistics. Licensing Agency Ltd.

[9] Wardhaugh, R. (2006). An Introduction to sociolinguistics. Blackwell.

[10] Yule, G. (2006). The study of language. Cambridge.

[11] Damayanti, W. (2005). Register Komunitas Musik pada Beberapa Restauran dan Hotel Berbintang di Kodya Surakarta. Unpublished Thesis. Universitas Sebelas Maret Surakarta.

[12] Usdiyanto. (2003). Register Militer: Kajian Sosiopragmatik (Studi Kasus di Sekolah Menengah Umum Taruna Nusantara Magelang)". Universitas Negeri Sebelas Maret Surakarta.

[13] Key, J. P. (September 23th 2021). "Descriptive Research". https://www.okstate.edu/aq/agedcm4h/academic/aged5980a/ 5980/newspage110.ht

[14] Madelina, tissa. (september 27th 2021). Pageant Lovers, Tim Sukses di Balik Gemerlap Mahkota Kontes Kecantikan. https://www.kapanlagi.com/showbiz/selebriti/pageant-lovers-tim-sukses-di-balik-gemerlap-mahkota-kontes-kecantikan-b72a3f.html 